\title{
Evaluation of Genetic Divergence in Black gram [Vigna mungo (L.) Hepper]
}

\author{
M.P. Arya Gopinath* , S.S. Desai, M.G. Palshetkar, \\ Hawaldar Ayyajahmad Harun and V.A. Raje Mahadik
}

\author{
Department of Agril. Botany, College of Agriculture, Dr. B.S.K.K.V Dapoli, Dapolitaluk, \\ Ratnagiri District, Maharashtra State, Pin: 415712, India \\ *Corresponding author
}

\begin{tabular}{|l|}
\hline Ke y w o r d s \\
Genetic diversity, Cluster, \\
$\mathrm{D}^{2}$ analysis, Black gram, \\
Inter-cluster distance, \\
Intra-cluster distance
\end{tabular}

A B S T R A C T

A field experiment was conducted to examine the genetic divergence among 64 Black gram genotypes at Research and Education Farm, Department of Agriculture Botany, College of Agriculture, Dapoli, Dist. Ratnagiri during rabi2017-18.Sixty four genotypes weregroupedinto9 different clusters on the basis of magnitude of D2 values evaluated by Mahalanobis D2 analysis. Among sixty four genotypes, 16 genotypes were clustered in to fourth and fifth cluster followed by cluster I having 13 genotypes. The cluster II included 10 genotypes, while cluster III had 5 genotypes. Cluster VI, VII, VIII and IX were monogenotypic. The maximum intra-cluster distance was observed in cluster V $(\mathrm{D}=9.108)$, while the lowest intra-cluster distance found in cluster I $(\mathrm{D}=5.865)$. The inter-cluster distance was high between cluster VI and VIII $(\mathrm{D}=46.48)$ and clusters VI and VII $(\mathrm{D}=37.06)$, there by indicated wide range of variation among the clusters formed. In contrast, the lowest inter-cluster distance (Between cluster I and II) suggested that the genetic constitution of the genotypes in both the clusters were in close proximity. Among the thirteen characters studied, 100 seed weight contributed maximum $(62.80 \%)$ followed by pod length $(18.60 \%)$ towards genetic diversity. Hence, these characters may be considered during selection of genotypes for further improvement and hence to increase the productivity.

\section{Introduction}

[Vigna mungo (L.) Hepper] $(2 \mathrm{n}=22)$ belongs to Leguminosae (Fabaceae) family, is an important pulse crop in India. Black gram [Vigna mungo (L.) Hepper] is one of the most ancient and important legume crop of India and contributes $70 \%$ of world's total production. It is suitable for cultivation under different farming situations. Urd bean occupies an important position due to its high seed protein $(25-26 \%)$, carbohydrates $(60 \%)$, fat $(1.5 \%)$, minerals, amino acids and vitamins and ability to restore the soil fertility through symbiotic nitrogen fixation. Among pulses, black gram is an important pulse crop, which is widely cultivated and consumed throughout India. The low productivity of black gram attributed to excessive vegetative growth, high rate of flower and fruit drop, non-synchronous maturity, pod shattering and susceptibility to diseases and Pests etc. Lack of good quality seeds and crop management, extremely limited use of rhizobial sources, phosphatic 
fertilizers, fungicides and pesticides also contribute to lower productivity. Improvement of urdbean being an important pulse crop of India, is an important task for pulses breeders. Many breeding efforts have been carried out to improve the yield of this crop and to break the yield plateau. Genetic diversity is an important factor and also a prerequisite in any hybridization programme. Analysis of genetic diversity in germplasm collections can facilitate reliable classification of genotypes and identification of subsets of core accessions with possible utility for specific breeding purposes. Also assessment of divergence or similarity among the genotypes would help in identification of genotypes that may be used in crossing programme to produce transgressive segregants. Genetic diversity arises due to either geographical separation, crossability barriers or due to different patterns of evolution.

\section{Materials and Methods}

A total of sixty four germplasm accessions of blackgram were subjected to divergence studies by $\mathrm{D}^{2}$ statistic. The investigation was carried at Research and Education Farm, Department of Agriculture Botany, College of Agriculture, Dapoli, Dist. Ratnagiri, Maharashtra state in rabi season 2017-18 in a randomized block design with three replications. Each genotype was sown in a three rows of 2.4 meter length with a spacing of $30 \times 20 \mathrm{~cm}$. Observations were recorded from five randomly selected plants from each genotype per replication for 13 characters like days to 50 per cent flowering, days to maturity, plant height $(\mathrm{cm})$,number of primary branches per plant, number of clusters per plant, number of pods per cluster, number pods per plant,100 seed weight(g), harvest index $(\%)$, protein content $(\%)$ and seed yield per plant $(\mathrm{g})$ and the average was taken for analysis. Recommended package of practices were followed to raise a good and healthy crop. The analysis of gentic divergence was carried out by using Mahalanobis $\mathrm{D}^{2}$ statistic as per Mahalanobis (1936) method and genotypes were grouped into different clusters following Tochers method as described by Rao (1952).

\section{Results and Discussion}

Genetic divergence analysis was carried out by calculating $\mathrm{D}^{2}$ values from the means of 64 genotypes of black gram for13 characters. Thus, the 64 genotypes were grouped into nine clusters (Table 1), which indicated a wide range of variation among the genotypes studied. It indicates that there is no relationship between geographic and genetic diversity as genotypes chosen from different eco-geographical regions are found to be in different clusters. Similarly based on the divergence Chauhan et al., (2008) studied 210 true breeding lines of urdbean and were grouped into nine different clusters and Elangaimannan et al., (2008) studied 55 genotypes of black gram were grouped into seven clusters. The cluster VI and V were emerged as the largest which consisted of 16 genotypes, followed by clusters I with thirteen genotypes, cluster II with ten genotypes and cluster III with five genotypes respectively. The clusters VI, VII, VIII and IX were solitary which consisted of the genotypes PLU-703, KU-16-13, AKU-14-3 and KU-18-87 respectively. The uniqueness of these genotypes placed them separately. From the clustering pattern, it was found that the genotypes collected from different regions were independent of their genetic origin. Hence, the genotypes studied are reliable enough for hybridization and selection. The intra and inter cluster $\mathrm{D}^{2}$ values are presented in the Table 2 and Figure 1. In the present study, it is indicated that the inter cluster distances were greater than intra cluster distances which shows considerable amount of genetic diversity existed among the genotypes. 
Table.1 Grouping of Black gram genotypes into different clusters by tocher method

\begin{tabular}{|c|c|c|}
\hline Cluster No. & $\begin{array}{l}\text { Number of } \\
\text { genotypes }\end{array}$ & Name of the genotypes \\
\hline $\mathbf{I}$ & 13 & $\begin{array}{l}\text { IPU-99-112,KU-16-8, IPU-94-1, PGRU-95014, KU-16-6, IPU- } \\
\text { 2K-1,KU-16-97, IPU-99-6, KU-11-5, KU-16-101, TBU-2, KU- } \\
\text { 16-5, KU-16-89 }\end{array}$ \\
\hline II & 10 & $\begin{array}{l}\text { IPU-99-213, HPU-120, IPU-99-12, KU-16-100, NO5/31, AKU- } \\
\text { 11-14, IC-50748,KU-16-11,KU-16-102, AKU-11-3 }\end{array}$ \\
\hline III & 5 & AKU-13-2,AKU-13-3, AKU-12-3, AKU-11-21, AKU-11-9 \\
\hline $\mathbf{I V}$ & 16 & $\begin{array}{l}\text { KU-16-98,KU-16-105, KU-96-3, KU-16-96, IPU-99-238, IPU- } \\
\text { 99-22, IPU-2-43, HPU-120,JU-4, NPU-180, AKU-14-2, KU-16- } \\
\text { 9, AKU-11-15,TBU-6,PU-19, IC-10703 }\end{array}$ \\
\hline $\mathbf{V}$ & 16 & $\begin{array}{l}\text { AKKU-1601,AKKU-1604,AKKU-1603, AKKU-1602, AKU-11- } \\
\text { 23, KU-16-12,AKU-11-12, KU-16-92, AKU-11-18, KU-16-90, } \\
\text { TU-91-2, PGRU-95018, PKGU-1, UH-218, PLU-250, U-135, }\end{array}$ \\
\hline VI & 1 & PLU-703 \\
\hline VII & 1 & KU-16-13 \\
\hline VIII & 1 & AKU-14-3 \\
\hline $\mathbf{I X}$ & 1 & KU-18-87 \\
\hline
\end{tabular}

Table.2 Average intra and inter cluster values in 9 clusters $\left(\mathrm{D}^{2}\right)$ in Black gram

\begin{tabular}{|c|c|c|c|c|c|c|c|c|c|}
\hline $\begin{array}{c}\text { CLUS } \\
\text { TER }\end{array}$ & I & II & III & IV & V & VI & VII & VIII & IX \\
\hline I & 32.40 & 83.37 & 251.66 & 119.35 & 87.13 & 218.27 & 665.06 & $\begin{array}{c}1226.0 \\
6\end{array}$ & 442.16 \\
\hline II & & 52.78 & 121.55 & 257.57 & 114.70 & 419.50 & 404.66 & 835.86 & 282.66 \\
\hline III & & & 49.66 & 511.06 & 247.73 & 772.38 & 196.86 & 466.54 & 166.70 \\
\hline$\overline{I V}$ & & & & 76.55 & 231.13 & 186.97 & 1127.25 & $\begin{array}{c}1812.3 \\
6\end{array}$ & 680.00 \\
\hline$\overline{\mathbf{V}}$ & & & & & 82.95 & 284.38 & 583.20 & $\begin{array}{c}1097.9 \\
5\end{array}$ & 467.07 \\
\hline VI & & & & & & 0.00 & 1374.06 & $\begin{array}{c}2160.4 \\
9\end{array}$ & $\begin{array}{c}1045.5 \\
0\end{array}$ \\
\hline VII & & & & & & & 0.00 & 123.14 & 330.03 \\
\hline VIII & & & & & & & & 0.00 & 575.85 \\
\hline$\overline{I X}$ & & & & & & & & & 0.00 \\
\hline
\end{tabular}


Table.3 Cluster mean performance of 13 characters in 64 genotypes of Black gram

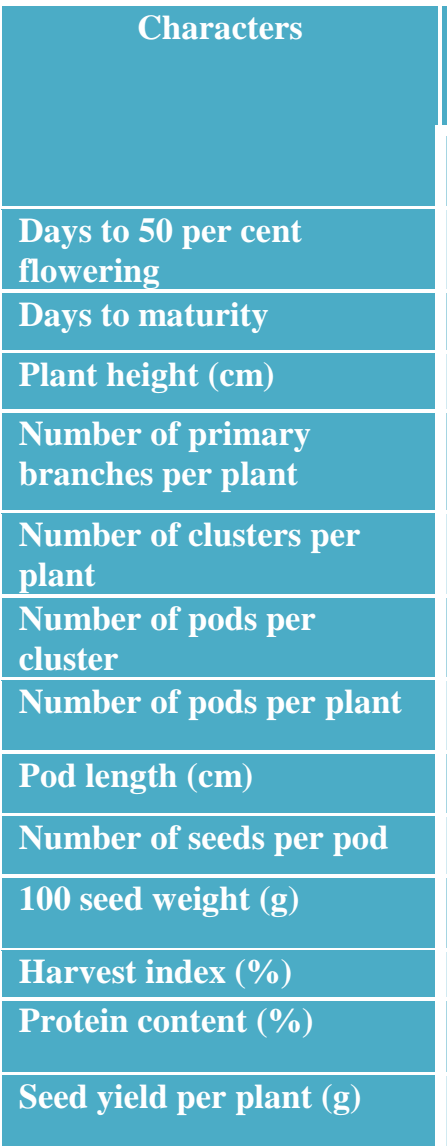

\begin{tabular}{|c|c|c|c|c|c|c|c|c|}
\hline \multicolumn{9}{|c|}{ Clusters } \\
\hline I & II & III & IV & V & VI & VII & VIII & IX \\
\hline 42.25 & 39.30 & 44.00 & 40.62 & 44.75 & 37.33 & 47.00 & 46.00 & 44.00 \\
\hline 92.82 & 87.86 & 94.00 & 90.06 & 95.12 & 86.33 & 96.33 & 95.66 & 93.66 \\
\hline 23.92 & 27.78 & 31.77 & 24.67 & 26.28 & 18.06 & 49.40 & 39.73 & 28.60 \\
\hline 8.63 & 9.73 & 9.48 & 8.64 & 8.94 & 5.60 & 6.73 & 11.06 & 6.40 \\
\hline 8.30 & 8.41 & 8.77 & 9.12 & 8.84 & 14.3 & 7.73 & 7.33 & 9.86 \\
\hline 3.32 & 3.70 & 3.62 & 3.61 & 3.51 & 4.80 & 2.73 & 3.80 & 5.86 \\
\hline 27.05 & 30.42 & 31.88 & 31.94 & 28.84 & 68.06 & 20.20 & 26.93 & 58.26 \\
\hline 4.95 & 5.11 & 5.71 & 5.38 & 4.60 & 4.04 & 4.93 & 5.46 & 6.19 \\
\hline 5.25 & 5.10 & 5.05 & 5.95 & 4.83 & 5.00 & 5.06 & 4.66 & 6.73 \\
\hline 4.34 & 4.76 & 5.21 & 3.86 & 4.51 & 3.75 & 5.97 & 6.57 & 5.33 \\
\hline 32.48 & 32.36 & 34.90 & 33.56 & 33.44 & 33.29 & 30.95 & 30.01 & 36.93 \\
\hline 23.84 & 24.20 & 22.55 & 23.23 & 21.48 & 19.30 & 24.55 & 22.29 & 25.38 \\
\hline 6.21 & 7.51 & 8.15 & 7.36 & 6.47 & 12.47 & 6.27 & 8.21 & 21.35 \\
\hline
\end{tabular}

Table.4 Contribution of various characters towards divergence in Black gram genotypes

\begin{tabular}{|c|l|c|}
\hline Sr No & \multicolumn{1}{|c}{ Characters } & Per cent contribution \\
\hline 1 & Days to 50 per cent flowering & $6.05 \%$ \\
\hline 2 & Days to maturity & $0.10 \%$ \\
\hline 3 & Plant height (cm) & $0.99 \%$ \\
\hline 4 & Number of primary branches per plant & $0.64 \%$ \\
\hline 5 & Number of clusters per plant & $1.74 \%$ \\
\hline 6 & Number of pods per cluster & $0.15 \%$ \\
\hline 7 & Number of pods per plant & $0.05 \%$ \\
\hline $\mathbf{8}$ & Pod length $(\mathrm{cm})$ & $18.60 \%$ \\
\hline $\mathbf{9}$ & Number of seeds per pod & $0.20 \%$ \\
\hline 10 & 100 seed weight $(\mathrm{g})$ & $62.80 \%$ \\
\hline 11 & Harvest index $(\%)$ & $4.02 \%$ \\
\hline 12 & Protein content $(\%)$ & $3.97 \%$ \\
\hline 13 & Seed yield per plant $(\mathrm{g})$ & $0.69 \%$ \\
\hline
\end{tabular}


Fig.1 Divergence based on clustering pattern ( $\mathrm{D}^{2}$ values) among urdbean genotypes

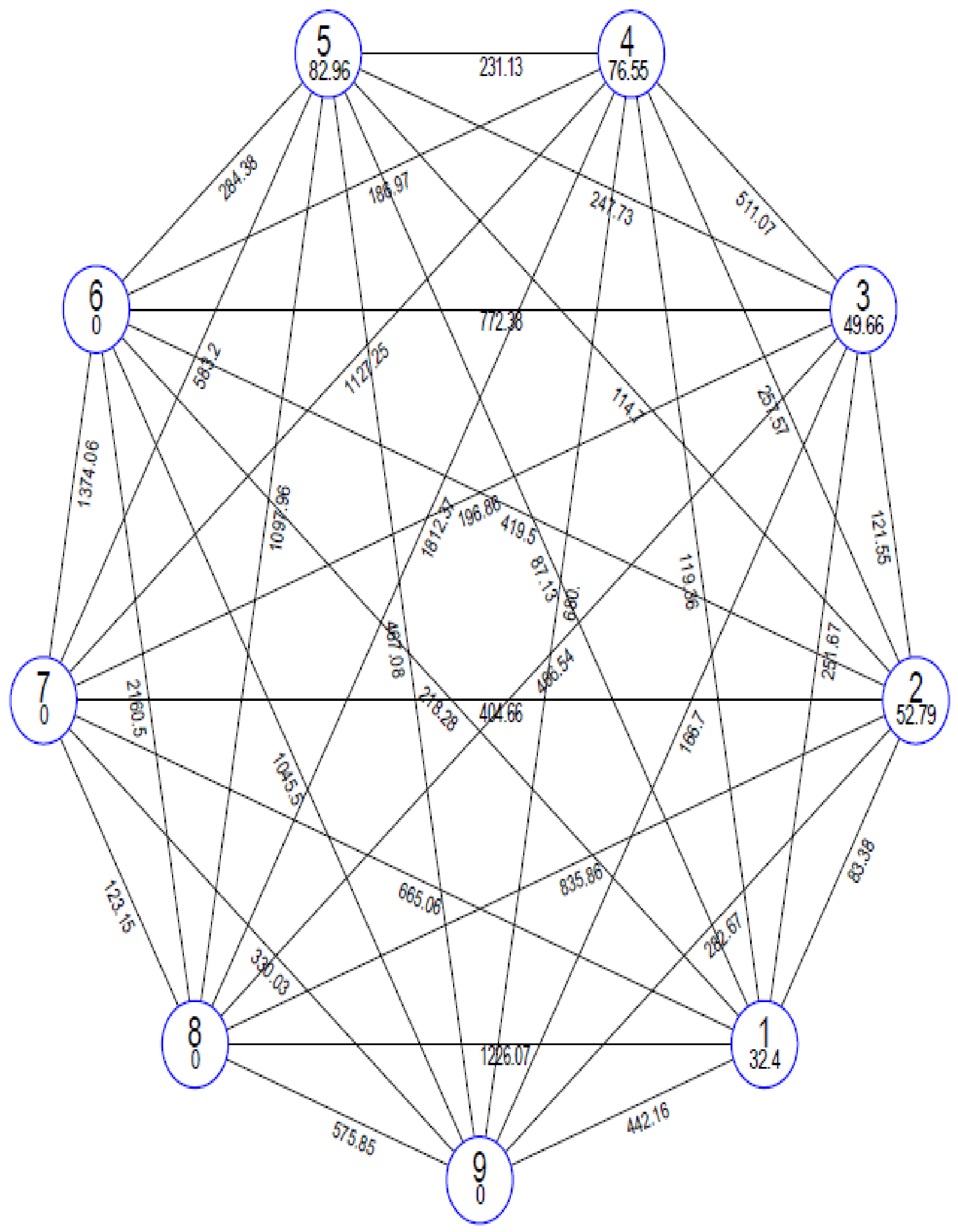




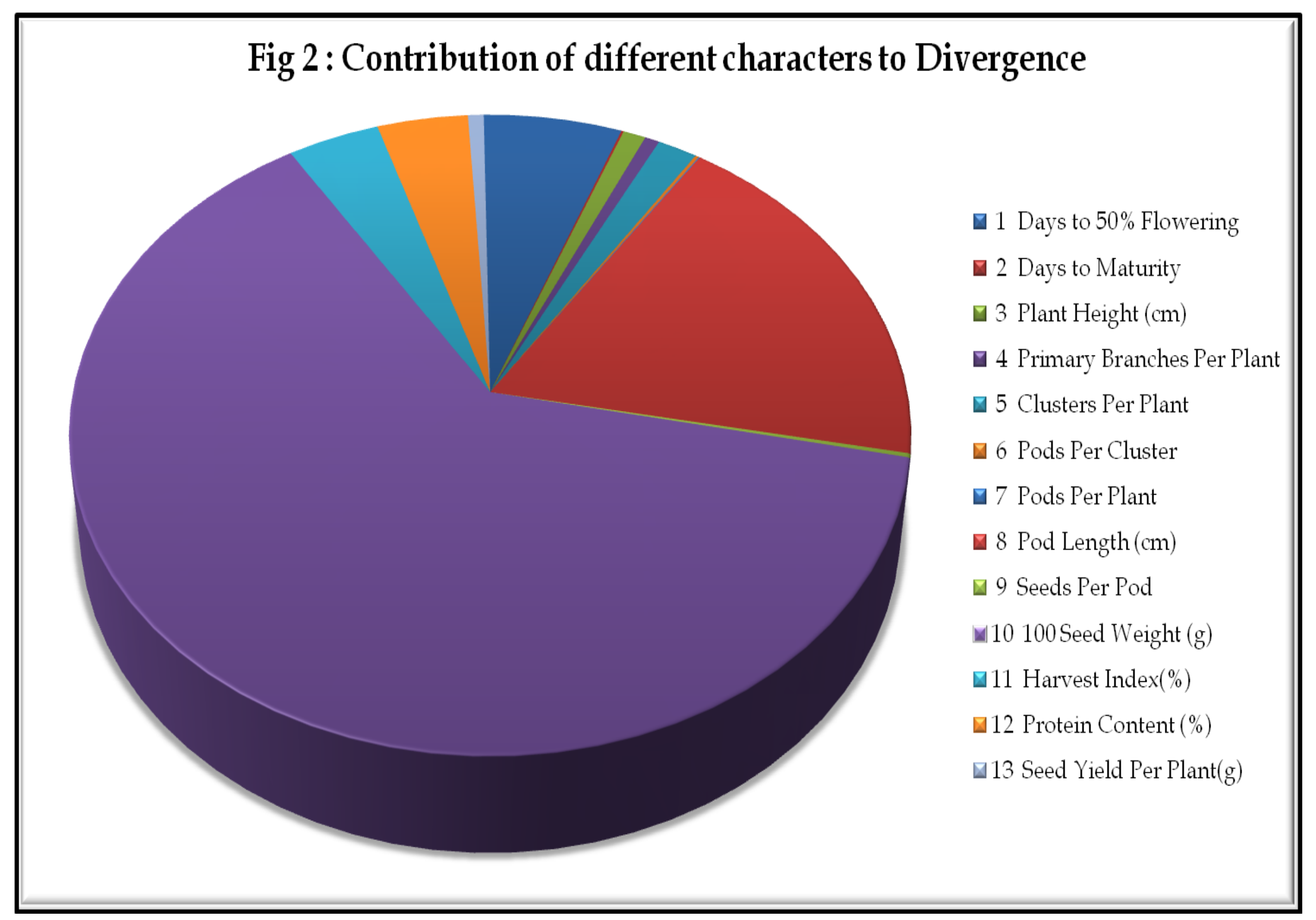


The maximum intra-cluster distance was observed in cluster V $(\mathrm{D}=9.108)$, thus suggesting that different genotypes included in this cluster might have different genetic architecture. However, the lowest intracluster distance found in cluster I $(\mathrm{D}=5.865)$ indicated that the genotypes resembled one another genetically and appeared to have evolved from a common gene pool.

The inter-cluster distance was high between cluster VI and VIII $(\mathrm{D}=46.48)$ and clusters VI and VII $(\mathrm{D}=37.06)$, there by indicated wide range of variation among the clusters formed. Hence, the genotypes in these clusters could be selected for hybridization to obtain desirable ones. In contrast, the lowest inter-cluster distance (Between cluster I and II) suggested that the genetic constitution of the genotypes in both the clusters were in close proximity.

Cluster VI recorded high mean values (Table 3 ) for number of clusters per plant (14.3) and number of pods per plant (68.06). High mean for days to 50 per cent flowering (47.00), days to maturity (96.33) and plant height (49.40) were showed by cluster VII, while cluster VIII had high mean value for number of primary branches per plant (11.06) and 100 seed weight (6.57). Cluster IX showed high mean value for all the remaining characters like number of pods per cluster (5.86), pod length (6.19), number of seeds per pod (6.73), harvest index (36.93), protein content (25.38) and seed yield per plant (21.35). Therefore, the genotypes selection among these clusters might result in simultaneous improvement of these traits.

Contributions of the characters towards divergence are presented in Table 4 and Figure 2. Out of 13 characters studied the character 100 seed weight $(62.80 \%)$ contributed the highest for divergence followed by pod length $(18.60 \%)$, days to 50 per cent flowering (6.05\%), harvest index $(4.02 \%)$, protein content $(3.97 \%)$, and number of clusters per plant $(1.74 \%)$. Hence, these characters may be considered during selection of genotypes for developing good yielding cultivars.

However, the contribution of plant height $(0.99 \%)$, seed yield per plant $(0.69 \%)$, number of primary branches per plant $(0.64 \%)$, number of seeds per pod $(0.20 \%)$, number of pods per cluster $(0.15 \%)$, days to maturity $(0.10 \%)$ and number of pods per plant $(0.05 \%)$ recorded lowest contribution for divergence.

The present investigation further revealed that cluster VI and VIII are most diverse to each other. Therefore, genotypes present in these clusters are suggested to provide a broadspectrum variability in segregating generations and may be used as parents for future hybridization programme to develop desirable genotypes.

\section{Acknowledgements}

Necessary facilities provided by Department of Agriculture Botany are acknowledged. Authors express their gratitude to Head of the department of Botany Dr. B.L. Thaware Sir and Dr. V.V. Dalvi (Associate Professor) for their valuable guidance and support.

\section{References}

Chauhan, M. P., Mishra, A. C. and Singh, A. K. (2008). Genetic divergence studies in urd bean (Vigna mungo (L.) Hepper). Legume Res, 31(1): 63-67.

Elangaimannan, R., Anbuselvam Y. and Karthikeyan P. (2008). Genetic diversity in black gram (Vigna mungo (L.) Hepper). Legume Res, 31 (1): 57 59. 
Mahalanobis. P. C. (1936). On the generalized distance in statistics. Proc. Natl. Acad. Sci. India, 12: 49-55.
Rao, C.R. (1952). Advanced statistical methods in biometrical research. John Wiley and Sons Inc., New York.

\section{How to cite this article:}

Arya Gopinath, M.P., S.S. Desai, M.G. Palshetkar, Hawaldar Ayyajahmad Harun and Raje Mahadik, V.A. 2018. Evaluation of Genetic Divergence in Black Gram [Vigna mungo (L.) Hepper]. Int.J.Curr.Microbiol.App.Sci. 7(08): 472-479. doi: https://doi.org/10.20546/ijcmas.2018.708.052 